\title{
What hope is there for South Africa? A public theological reflection on the role of the church as a bearer of hope for the future
}

\begin{tabular}{|c|c|}
\hline $\begin{array}{l}\text { Author: } \\
\text { Dion A. Forste }\end{array}$ & \\
\hline $\begin{array}{l}\text { Affiliation: } \\
{ }^{1} \text { Faculty of The } \\
\text { Systematic Th } \\
\text { Ethics, and Pu } \\
\text { Stellenbosch } ~ \\
\text { South Africa }\end{array}$ & $\begin{array}{l}\text { eology, } \\
\text { eology, } \\
\text { blic Theology, } \\
\text { Jniversity, }\end{array}$ \\
\hline $\begin{array}{l}\text { Corresponden } \\
\text { Dion Forster }\end{array}$ & ce to: \\
\hline $\begin{array}{l}\text { Email: } \\
\text { dionforster@s }\end{array}$ & un.ac.za \\
\hline $\begin{array}{l}\text { Postal address } \\
171 \text { Dorp Stre } \\
7600 \text {, South A }\end{array}$ & $\begin{array}{l}\text { et, Stellenbosch } \\
\text { frica }\end{array}$ \\
\hline $\begin{array}{l}\text { Dates: } \\
\text { Received: } 27 \mathrm{~A} \\
\text { Accepted: } 29 \\
\text { Published: } 29\end{array}$ & $\begin{array}{l}\text { ug. } 2014 \\
\text { an. } 2015 \\
\text { Apr. } 2015\end{array}$ \\
\hline $\begin{array}{l}\text { How to cite th } \\
\text { Forster, D.A., } \\
\text { hope is there } \\
\text { Africa? A publi } \\
\text { reflection on t } \\
\text { the church as } \\
\text { of hope for the } \\
\text { HTS Teologiese } \\
\text { Theological St } \\
\text { Art. \#2814, } 13 \\
\text { dx.doi.org/10. } \\
\text { v71i3.2814 }\end{array}$ & $\begin{array}{l}\text { is article: } \\
\text { 2015, 'What } \\
\text { or South } \\
\text { ic theological } \\
\text { he role of } \\
\text { a bearer } \\
\text { e future', } \\
\text { Studies/ } \\
\text { udies } 71(1) \text {, } \\
\text { pages. http:// } \\
4102 / \text { hts. }\end{array}$ \\
\hline $\begin{array}{l}\text { Copyright: } \\
\text { (c) 2015. The A } \\
\text { Licensee: AOSI } \\
\text { OpenJournals. } \\
\text { work is license } \\
\text { the Creative C } \\
\text { Attribution Lic }\end{array}$ & $\begin{array}{l}\text { luthors. } \\
\text { IS } \\
\text { This } \\
\text { d under } \\
\text { ommons } \\
\text { ense. }\end{array}$ \\
\hline 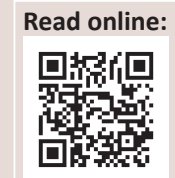 & $\begin{array}{l}\text { Scan this QR } \\
\text { code with your } \\
\text { smart phone or } \\
\text { mobile device } \\
\text { to read online. }\end{array}$ \\
\hline
\end{tabular}

What hope is there for South Africa? What role can the church play as a bearer of hope in South Africa? This article seeks to address these important questions. Firstly, it problematises the contemporary notion of hope in South Africa by showing that it is a complex theological and social concept. Next, a nuanced understanding of hope is presented by adopting a public theological methodology that brings dominant theological perspectives on eschatological hope into dialogue with the most recent statistics about the quality of life in South Africa from 1994, 2004 and 2014. The article proposes that the complexity of Christian hope necessitates an understanding of the present reality that is held in dynamic tension with the desired future namely a present-futurist eschatology. Finally the article shows that from this vantage point the church, in its various forms and understandings, is able to be a bearer of Christian hope that can contribute towards shaping a better future for South Africa.

\section{Introduction}

South African society has changed radically in the 20 years since the dawn of participative democracy on the 27th of April 1994. It is wise to pause at this point and ask the question: 'What will the next 20 years of democracy hold for South Africa and for South Africans?' Theologians in particular have a great interest in understanding the role that Christians and the church will play in South Africa in the next decades. What role can, and should, the church play in the future of South Africa? What is the nature of hope for South Africa? How can the church and Christians be bearers of hope for the nation in the coming decades?

These questions are very difficult to answer decisively. The first thing that that this article will do is to problematise the problem - in other words we shall reflect deeply and critically on the source, content and reason for our Christian hope. Secondly, we will try to engage the current status of South Africa and South Africans in the form of the question - is the 'average' South African better off today than in 1994? In answering this specific question the article will present the most recent statistics about the quality of life of South Africans today, compared to 1994. Thirdly, in order to answer the question about the church being a source of hope in society the article answers the question: 'What is the church, which church will offer hope, and how shall it do so?' Finally this article offers some reflections, based on the above discussion, to see how Christians and the church can be vessels and bearers of hope in South Africa in the decades ahead. ${ }^{1}$

\section{I don't know: The three hardest words in the English language}

In order to look forward we do need to look back. However, in doing so we must take care not to make the mistake of thinking that even the most comprehensive of studies of our recent past would be a sure-fire recipe for predicting what will happen in the future, or indeed what should happen in the future. As the Danish physicist, Niels Bohr, rightly said: 'Prediction is very difficult, especially if it is about the future' (Niels Bohr quoted in Dubner \& Levitt 2014:37; also see Ellis 1970:431).

Theologians, particularly Systematic Theologians, like to work with (relative) certainties - simply put, we quite like giving answers! As philosophers of religion Systematic Theologians feel most comfortable when wading in the waters of truth (Ford 2013:4-5). Such an approach to life has frequently led to the accusation that theologians in particular, and perhaps Christians in general,

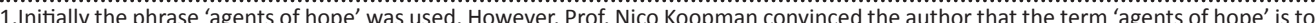
1.Initially the phrase 'agents of hope' was used. However, Prof. Nico Koopman convinced the author that the term 'agents of hope' is too
strongly focused on human agency. Thus it was decided to use the phrase 'bearers of hope' instead. Indeed, we are carriers or bearers strongly focused on human agency. Thus it was decided to use the phrase 'bearers of hope' instead. Indeed, we are carriers or bearers
of hope, God's hope, we do not construct hope, we bear witness to it, we unearth it and lead others to it. Thus the terms vessels and bearers of hope are used in this context. See Koopman (2014) for a detailed discussion on this issue. 
are ultracrepidarianists (Dubner \& Levitt 2014:42-43). If one happens to be a public theologian one is at an even greater risk of being given this label, since it is the task of the public theologian to find ways of relating the importance of our faith to critical social issues, particularly those issues that are of most significant public concern and interest. ${ }^{2}$ Van Aarde (2008) writes:

The social location of public theologians is not the university campus, but rather the public square - in other words, the modern-day agora - wherever it may be situated in the 'global village' or in the cyber space. ( pp. 12-16)

John de Gruchy's (2013) wonderful new book Led into mystery is most helpful at this point - the title of the book was inspired by a remark made by the Catholic Systematic Theologian Karl Rahner concerning the nature of theology, namely that theology is reductio in mysterium - (literally being drawn back into mystery) (De Gruchy 2013:4; Rahner 1992:335). In this book we are once again reminded that as Christians we cannot trade on certainties concerning the future, particularly if the source of those certainties is our own reason. Scientific knowledge, historical records, empirical data are not sufficient to explain some of the great mysteries of life. In fact for people of faith, mere facts cannot be the primary currency of our hope (De Gruchy 2013:211-214). Our faith allows us to live with hope in the midst of factual or historical uncertainty. It is not easy to live with uncertainty. To live hopefully in a situation of uncertainty requires great faith, this is uncomfortable, even untenable, for many persons.

Steven Levitt, Professor of Economics at the University of Chicago, summed up this tension so nicely in his book 'Think like a freak': ${ }^{3}$

It has long been said that the three hardest words to say in the English language are I love you. We heartily disagree! For most people, it is much harder to say I don't know. That's a shame, for until you can admit what you don't yet know, it's virtually impossible to learn what you need to. (Dubner \& Levitt 2014:33)

What do the next 20 years hold for South Africa? I admit, reluctantly, that I don't know. Thankfully uncertainty places us in fairly good company. Jürgen Moltmann (1993) writes of the phenomenon of uncertainty and the future saying:

The modern consciousness of history is a consciousness of crisis, all modern philosophy of history is in the last analysis

\begin{abstract}
2.The discipline of Public Theology is gaining prominence in scholarly theological discourse. There are a variety of understandings of the discipline of Public Theology and the approach of the public theologian. However, they seem to converge in the idea that theology has a valid and necessary role to play in public discourse, and idea that theology has a valid and necessary role to play in public discourse, and
that matters of public concern should be engaged theologically (both for the sake that matters of public concern should be engaged theologically (both for the sake
of making a public theological contribution, but also to reflect upon and shape our theological perspectives on the world, our own lives and God). Please refer to Smit's (2013) article The paradigm of public theology - Origins and development for a helpfu historical overview, and philosophical analysis, of the development of the term 'public theology' and development of the discipline of Public Theology in theological discourse. It is also worth noting that the discipline and terminology are contested in South African theological discourse, please see the following articles as two prominent examples of the diverse perspectives on the role and place of public theology in South Africa (Maluleke 2011; Koopman 2011). Tshaka (2014:4-5) has a very insightfu South Africa (Maluleke 2011; Koopman 2011). Tshaka (2014:4-5) has a very insightful social cohesion and public theology in which he offers a balanced and nuanced view of the role of public theology in the South African context.
\end{abstract}

3.A word of caution to the reader, some rather eclectic titles have been chosen for the chapter headings. They come from Dubner and Levitt's book Think like a freak (2014), it is hoped that the unconventional titles will hold the reader's attention, and that they will aid in clarifying the argument of this article as it unfolds. a philosophy of crisis. Modern man's [sic] epochal experience of history is grounded in the experience of infinitely new and overwhelming possibilities which cannot be mastered by customary methods of his traditions. (p. 230)

Let's consider this for a moment: Who would ever have predicted around the time of the 1994 elections, that 20 years later young radicals from the Economic Freedom Fighters (EFF) wearing red berets and red 'overalls' would be sworn in as parliamentarians, having captured 25 parliamentary seats in the 2014 South African National Elections? ${ }^{4}$ The rise of the EFF has signalled a major shift in South Africa's political landscape. It unmasks the massive economic and social inequality that exists in South Africa, giving voice to millions of disgruntled and disenfranchised South Africans who have not experienced any substantial change in their quality of life under democratic rule.

What this shows is that it is very difficult to predict the future.

While we cannot predict the exact shape of our future, there are some theological constants that should carry us forward in hope. Together with this we can also look back from our current vantage point and see how we arrived here. Once more we draw on the wisdom of Jürgen Moltmann who has the following to say concerning hope and history: ${ }^{5}$

One cannot gain a future unless one is prepared to search one's past and to acknowledge and accept one's present, however distasteful that may be. To forget the past and to suppress its memory brings into being neither a future nor a fresh hope. Even hope has its memories, for hope too is rooted in the past. (cited in Meeks 1974:ix)

If we accept this to be true then we will need to look back in order to look forward, but as we shall discover we will also need to look forward in order to live backwards. As Prof. Elna Mouton once said, 'Remembering forward, hoping backward' (Mouton 2001).

\section{What is hope?}

What is the nature of our hope for South Africa? Moreover, what is Christian hope? What does it mean in our current social and historical context? These important questions deserve some consideration at this point.

\section{What is Christian hope?}

A good place to begin to understand the future for South Africa, and the role of Christians and the church in this

4.'EFF makes ANC see red' (2014) These 'red radicals' illustrate how unpredictable history can be! Of course we can deconstruct the situation that has led to their popular acceptance. In the first instance they serve as a very real reminder of the current political crisis in South Africa and the social and economic concerns that underpin it. This widely publicised political event is one of the unintended and unpredictable, consequences of our recent past. The red 'overalls' are powerfully disruptive symbol, used in an ingenious manner, intending to show that powerfully disruptive symbol, used in an ingenious manner, intending to show that the governing African National Congress (ANC), which was itself a radical liberation movement in the run-up to the 1994 elections, has become the 'establishment',
losing touch with many of South Africa's unemployed and working class citizens.

5.Please see the following dissertation for an excellent location of Moltmann's understanding of hope and eschatology with particular relation to the South African context (Bentley 2004, 2008, 2013). 
future, is to consider the nature and character of Christian hope. Or, as Levitt and Dubner say, 'like a bad [hair] dye job, the truth is in the roots' (Dubner \& Levitt 2014:91).

The point that that these authors make is that very hard problems are very hard to solve. If one considers complex issues such as global warming, the global economic crisis, or perhaps a little closer to home we may consider the problems of land redistribution, economic inequality, lack of service delivery, or corruption - these are extremely difficult problems to engage effectively. ${ }^{6}$

Our neuro-evolutionary development shows that because humans are 'survival' and 'efficiency' systems, we fall prey to the trap of the 'proximate cause' when we try to solve complex problems (Dubner \& Levitt 2014:92). Explained succinctly, human evolutionary development has caused us to seek solutions to problems that are in close proximity to the problems themselves. In the primal era it was a matter of life or death to know whether a particular type of berries that were close to one's home were poisonous or edible. Even in contemporary situations the proximate cause is often the one that makes most sense, as Dubner and Levitt explain, if your three-year-old child is wailing his lungs out and your fiveyear-old is standing close by with a devilish grin and a plastic hammer in his hand, it is most likely that the hammer and the five-year-old have something to do with the wailing (Dubner \& Levitt 2014:93). Centuries of proximate cause solutions have led us to try and solve most problems in this manner. ${ }^{7}$

The challenge is, however, that we soon come to realise that the more complex problems in life such as illnesses, political dysfunctions, global climate issues, are not easily solved by proximate causes. Often the real cause of a problem lies further away, and so does the solution. Theoretically we could solve poverty, for a short while at least, by distributing bags full of money to poorer communities - that would be a proximate cause solution. However, we would soon discover that this is neither a sensible nor a sustainable solution to the problem. Sadly, this is most frequently the way in which we respond to problems. ${ }^{8}$ David Korten (1990:117-118) would call these kinds of 'solutions' first and second generation engagements. We will say more about Korten and his generational theory in a later section of this article.

This brings us back to the issue at hand - do we truly understand the problem that we are trying to solve in South Africa? What

\footnotetext{
6.Sadly the church has not always been effective in addressing such complex issues
effectively and concretely. One consequence of this is that there is a growing sense of effectively and concretely. One consequence of this is that there is a growing sense of
distrust, and even opposition, to the church among young black South Africans who feel that the church has not delivered solutions to the nations problems, and at times even betrayed their hopes (Gibson 2012:51, 61; Please also see the following nuanced argument on spirituality social conditions among black South Africans, Tshaka 2014:5-6). This is evidenced in the statistical changes in church membership decline among black South African youth in mainline churches (Erasmus 2012:48-50,55).

7.'"Starvation is the characteristic of some people not having enough food to eat'" the economist Amartya Sen wrote in his landmark book Poverty and Famines. "It is not the characteristic of there being not enough food to eat." In countries whose not the characteristic of there being not enough food to eat." In countries whose rather than the multitudes, food is routinely withheld from the people who need it most' (Dubner \& Levitt 2014:93).

8.This issue is discussed at length, in relation to the church's response to environmental and social issues in the article (see Forster 2008).
}

exactly would hope be for the nation, the people of South Africa, and their neighbours? Where does hope lie? Is there even a certainty of hope given the current challenges we face in South Africa? A review of the current discourse of hope, and hopelessness, shows that there are very few South Africans who are giving these questions deep and sustained thought.

Within the ambit of such uncertainty it is, however, still possible to give some expression to the content of the Christian message of hope. John de Gruchy's advice serves as a guide in this endeavour. He says that the 'language of hope will vary as the context demands, but the message remains' (De Gruchy 2013:211).

In June 1968 the South African Council of Churches (SACC) published 'A message to the people of South Africa' (cf. SACC 1968; Naude 1995:167), it begins with a series of faith commitments and affirmations. The final three commitments, which appear before the 'message', are the following:

- The Gospel of Jesus Christ declares that God is the master of this world and that it is to him alone that we owe our primary commitment.

- The Gospel of Jesus Christ declares that the Kingdom of God is already present in Christ, demanding our obedience and our faith now.

- This Gospel of Jesus Christ offers hope and security for the whole life of man [sic], not just man's spiritual and ecclesiastic relationships, but for human existence in its entirety. (SACC 1968; also quoted in Naudé 1995:167)

When one considers what was to take place in South Africa between 1968 and 1994, this message of hope and challenge to the church (and broader society) is particularly poignant and powerful.

'A Message to the people of South Africa' was a comprehensive theological rejection of the rising social ill of apartheid that was breaking apart the nation with ever increasing intensity (SACC 1968). Hayes notes that while there had been many other critiques by churches and church leaders against the effects and application of the unjust system of apartheid, this was the first time the South African church had so strongly condemned the principle of apartheid in South Africa (Hayes 2008; please see the following very helpful historical reflection on this period in South African Church history, Plaatjies-Van Huffel \& Vosloo 2013:147-157). Sadly, the 'Message' did not receive the anticipated media coverage since it coincided with the government's banning of the MCC cricket tour because the touring English cricket team included a South African born person of colour named Basil d'Oliveira. Notwithstanding, this powerful statement came to shape much of the church's response in both word and deed in the years that followed.

The 'Message' is, as John de Gruchy has said above, theologically timeless, and is once again of interest in two particularly instances. Firstly, it reminds both the nation and the church that its true source of hope and security is to be 
found in the Gospel of Christ. Specifically, from the Public Theological perspective, it locates the ambit of faith, and the consequences of belief in Christ, within the public sphere. Faith in the Gospel of Christ has a concrete expectation for the way in which Christians live in the world, how they relate to other persons, how they form their laws, and how they work towards justice and human flourishing. ${ }^{9}$ In short, the Christian faith has significant social and political consequences that reach beyond the walls of the worshipping congregation.

Secondly, it presented, in an embryonic form, the characteristics of a theology that would categorise critical thought among South Africa's Christians for years to come. These categories of theology were later expressed most clearly in the Kairos document in 1985 (Kairos Theologians 1985). The Kairos declaration showed that South African Christians tended to engage their faith and the world from three general theological perspectives, namely church theology, state theology and prophetic theology. It would be well worth considering what kind of theology dominates the pulpits, Synods and the conversation of South African church members at present? Is it church theology, perhaps even state theology, or is there evidence of a healthy vibrant prophetic engagement with institutions of power in society?

The point is simply this - our Christian hope should be informed by a clear expectation that our work, and witness in the present will shape what we hope for in the future.

\section{Hope and eschatology - what is the relationship between the future and the present?}

Thus, we should not only be asking: 'What do the next 20 years hold for South Africa?', but also: 'What is the nature and role of the church at present that will bring about the future we hope for in the next 20 years?'

Stanley Hauerwas (2013) places the importance of this eschatological hope, and present expectation, in stark relief when thinking of the role and nature of the church. Simply stated he says that we need to ask two pointed questions concerning the church in relation to our eschatological expectation; our future hope. The questions we are to ask are: What is it [the church] for?' and 'Who does it serve?' He goes on to say that the 'recovery of the eschatological vision is crucial for how the church understands her relation to the world' (Hauerwas 2013:ix-xi).

Needless to say, any possible answers to Hauerwas's questions are deeply theological, they are missiological in nature since they have to do with Christian identity, witness and work. Moreover, they are also of sociological and political concern. Hauerwas clarifies what is meant by this in saying that the church does not so much have a political mission as her very existence is a political mission; it provides an alternative to the politics of the world' (Hauerwas 2013:xii).
J.M. Vorster describes this perspective on hope and eschatology, employing Hans Küng's term, a 'present-futurist eschatology of hope'. Küng understood that the term presentfuturist eschatology describes 'the reign of God, which irrupts into the present, takes on power in the present and is fulfilled and completed in Jesus' (Küng 1992:59; Vorster 2011:7-8).

The premise is that the culture of a society in general, and the church in particular, are driven forward and shaped by that community's expectation of what is to come. This theory has found great support since the ground-breaking work of the Dutch scholar Frederick Polak $(1968,1971) .{ }^{10}$ The central concept that Polak proposed as a result of years of research was that when we look at each age, or epoch of history we can see that it was shaped by an expectation of the future that formed the ideals, plans and actions of people in the preceding age (Polak 1968:18). This is important, but it is not quite what we mean by a 'present-futurist eschatology of hope'. Polak's view is grounded in social and historical theory, whereas our primary point of departure as Christians is formed by our faith, our theology, our witness (together with social and historical theory). Thus, it is not our desired future towards which we plan, act and live, but rather God's desired future.

Christiaan Hermans (2012) describes this as 'unlocking the future that is waiting to emerge':

The future is like the prisoner in the marble waiting to be set free by the sculptor's hand. The image suggests that it is not the sculptor who imposes a form on the marble. The form is already there in the marble. (p. 250) $)^{11}$

Vorster (2011) concurs with this view noting that in Christian theology we will find that our eschatology, our understanding of God's ultimate reign, has shaped both our beliefs and our actions throughout history. Hence, an eschatology of hope is:

$[A] \mathrm{t}$ the same time a reality and a promise. It is here (present) but will reach its fulfilment with the end of human history. The time between the promise and initial irruption of the Kingdom and the final fulfilment of the promise is a 'Zwischenraum' where the church is sent into the world to proclaim the message of hope. (Vorster 2011:7)

Such a view of history and theology has profound implications for the current work and identity of the church.

If we anticipate a future of God's choosing and design, then the people of God must live towards that future with courage and commitment. In Timothy Harvie's recent study entitled, Jürgen Motlmann's ethics of hope (2009), he makes the concrete link between Moltmann's eschatological hope and the church's present action:

If theology and the Church live from the end, then it may be argued that the importance of eschatology is not merely for

10.For a helpful summary of Polak's research please consult Vorster $(2011: 6-8)$.

11.Hermans develops the notion of 'presencing' the future using the following theoretical framework (Scharmer 2009:2, 7). Once again this can be linked to Nico Koopman's understanding of Christians as bearers and vessels of hope, rather than Koopman's understanding of Christians as bearers and vessels of hope, rather than
agents of hope - God is the primary mover, the active agent, we are co-labourers, partners and witness that usher in God's hope for the world. 
missiology and soteriology alongside its usual association with the 'last things', but it also has much to say in regard to Christian ethics. (p. 1)

What future does God hope for in South Africa? If we were to think of the nation 20 years from now, and of course the church in the nation 20 years from now, what does God long for? This vision should shape how and who we are as a church at present.

At the winter school of the Faculty of Theology at Stellenbosch University, Nico Koopman remarked that to be Christian is to be involved in protest (Koopman 2014). The Latin word, from which we derive the English word, is prötestārī. It means to declare publicly, prō (towards or for) and testāri We are called to protest, to bear witness, wherever we see God's hope, but also where we see it is absent. This is part of the present work of the church. It involves our worship, our liturgy, our service in society, and our presence in the public sphere. John van de Laar (2010:20) says it so simply and beautifully: 'The way we worship defines the way we live'. All of these are elements of protest, a protest for God's hope in the world.

\section{Is there hope at present? Is life better for the 'average' South African in 2014?}

In the previous section we clarified the question of our hope by placing it within the firm theological perspective of eschatology. In particular we showed that our future hope and our current identity and work are intrinsically linked.

The core question we could ask is whether South Africa is in a better place today than it was 20 years ago? The President of South Africa, Jacob Zuma, suggests that it is: 'South Africa is a much better place to live in now than it was in 1994 . Indeed we have a good story to tell' (South Africa 2014). Is it possible to measure whether this confidence is founded in fact, or whether it is merely political rhetoric?

Firstly, there is one area in which South Africa is most certainly better off in 2014 than it was before the 1994 elections, and that is that the citizens of the nation live within a constitutional democracy. The importance and significance of this cannot be underestimated. It is of critical importance. But a change in law was only the start of the change that was necessary in South Africa.

Dirkie Smit (2007) comments on this sudden change of legal status in South African society when he writes:

The 'miracle' of the 'rainbow-nation' was in the first place and certainly in the first phase a political miracle... The collapse of the apartheid regime and the miraculous political transformation, however, only paved the way for the real, radical and lasting changes, affecting every aspect of society. (p. 59)
His comment is made within an understanding that South African society 'collapsed into modernity' overnight:

Social, economic, cultural, educational, legal, intellectual, and indeed political transformations that took centuries to develop in some countries, particularly in the West, have been happening here within just more than a decade. (Smit 2007:59)

It is now almost a decade since Smit's article was written, and we have seen the initial euphoria and expectation of the rainbow nation being replaced with a stark, and even critical, realism (see introduction \& chapter 3 of Mashele \& Qobo 2014). As mentioned in the introduction of this article, the rise of the EFF signals a turn in the public perception of the post-apartheid African National Congress (ANC). Service delivery protests, public and political scandals, as well as widespread dissatisfaction with the pace of change require that we ask whether South Africans truly are better off 20 years after the dawn of our participative democracy?

In 2011 the Organization for Economic Co-operation and Development (OECD) ${ }^{12}$ developed the Better Life Index (BLI) that measures well-being on 11 dimensions across two broad domains. The two domains are listed below, with the 11 dimensions following in brackets:

- Domain 1: Material living conditions (income and wealth, jobs and earnings, housing).

- Domain 2: Quality of life (health status, work-life balance, education and skills, social connections, civic engagement and governance, environmental quality, personal security, subjective well-being) (OECD 2013a:1731, 2013b).

While there was not sufficient, or reliable, data for each of the 11 domains, the survey was able to gather sufficient data for at least six of them, namely: health, education, crime and violence, housing and living conditions, human development, and the economy, income and employment. The data was considered in 10 year increments (i.e. 19942004 and 2004-2014).

The first set of information we see below is the population profile. This tells us that while the population has grown, our growth rate is declining (from $1.1 \%$ in 1994 to $0.2 \%$ at present). It also shows that our population is ageing, as is shown by the increase in the median age (22 in 1995 to 27.8 by 2015). The number of persons between the ages of $15-65$ is also increasing steadily (from 58\% in 1994 to $65.8 \%$ in 2014). Lastly we can see that we are facing significant urbanisation $(54.5 \%$ of SA citizens lived in urban areas in 1994 , compared to an expected $63.8 \%$ by 2015 ) (Haldenwang 2014:1) (Figure 1).

Let's consider some of the details of the $\mathrm{BLI}^{13}$ to see if we can answer the question: 'Are South African's better off after

12.To find out more about the OECD please visit their website at: http://www.oecd. org/

13.All of the information in the graphs, as well as the analysis of them, is based on the following reports, (Actuarial Society of South Africa 2011; also see, Haldenwang 2011, 2014:2-6; United Nations Development Programme [UNDP] 2012). 


\begin{tabular}{|l|ccc|}
\hline \multirow{2}{*}{ Indicator } & \multicolumn{3}{|c|}{ Year } \\
\cline { 2 - 4 } & $\mathbf{1 9 9 4}$ & $\mathbf{2 0 0 4}$ & $\mathbf{2 0 1 4}$ \\
\hline Population size $(\mathrm{m})^{\mathrm{a}}$ & $40.73(41.19)$ & $48.11(47.68)$ & $51.62(52.20)$ \\
Annual population growth rate (\%) & 1.13 & 0.71 & 0.20 \\
& $(1991-1995)$ & $(2001-2005)$ & $(2011-2015)$ \\
$\%$ aged 0-14 & 36.7 & 31.9 & 28.0 \\
$\%$ aged 15-64 & 59.0 & 63.1 & 65.8 \\
$\%$ aged 65+ & 4.3 & 5.0 & 6.2 \\
Median age (years) & $22.0(1995)$ & $24.5(2005)$ & $27.8(2015)$ \\
Urbanisation level (\%) & $54.5(1995)$ & $59.3(2005)$ & $63.8(2015)$ \\
\hline
\end{tabular}

ain superscript figures in brackets are according to the ASSA2008-model.

Source: Actuarial Society of South Africa, 2011; Haldenwang, 2011; UN, 2012.

Source: Haldenwang, B., 2011, Projections of the South African population, 1985-2040 (With-AIDS and No-AIDS projections), Stellenbosch University, Bellville

FIGURE 1: Population profle, 1994, 2004 and 2014.

20 years of democracy?' We shall do so under a number of sub-headings.

Health status: The health of the 'average' South African is better today than in 1994. We have increasing life expectancy, we have declining rates of maternal mortality and a decline in HIV infections and AIDS-related deaths. We also have better food security and an increase in the ratios of health care workers, while there is a decline in the number of persons who smoke. That being said, TB and HIV/AIDS remain significant challenges to the South African population (Figure 2). ${ }^{14}$

Education status: The educational status of the 'average' South African has improved at almost all levels (from adult literacy to early child development). The decline in the number of primary school registrations can be attributed to the decrease in the number of children of that age over the period of the survey. While there are generally higher enrolments and pass rates, there is a grave concern about the standard of South African education. South African learners continue to perform very poorly in comparison to learners from other nations. The Anglican Church of Southern Africa felt that it was the politicisation of education through the South African Democratic Teachers Union (SADTU) that must take some of the blame for this (SAPA 2013). Whatever the cause may be, we do have a crisis in education in South Africa. This does not bode well for future of South Africa (Figure 3).

Crime and violence: While some would disagree, the data show that violent crimes are decreasing. The 'average' South African experienced less incidences of murder, sexual offences and violent robbery. However, the so-called 'trio crimes', house robbery, business robbery and vehicle hijacking remain on the increase (Figure 4).

Human development: The effects of HIV on the 'average' South African turned at their peak in 2005, since that point there has been an increase in South Africa's Human Development Index. This is shown through a rising life

14.Please refer to the following reports, (Actuarial Society of South Africa 2011 Human Sciences Research Council [HSRC] 2013; Health Systems Trust 2014; World Health Organization [WHO] 2014). expectancy, increase in the number of years of schooling, and rising Gross National Income (GNI) per capita (Figure 5).

Housing and living conditions: It is encouraging to note that South Africa has more persons living in formal dwellings in the last 20 years. Access to clean water, sanitation, electricity and refuse removal have also increased in urban areas. While this is the case almost 2 million households live in informal dwellings, of which 1.3 million have no access to reliable clean water (piped tap water), and 1.4 million households still use bucket toilets (or less sanitary solutions) (Figure 6).

Economy, income and employment status: South Africa showed some promising prospects in relation to economic growth and the inflation trajectory between 1994 and 2004. In the period since (2004-2013) there has been a deterioration in economic growth, dropping from 4.6\% per annum in 1994 to $1.9 \%$ per annum in 2013. Inflation has increased from $1.4 \%$ in 2004 to $5.7 \%$ in 2013. This can be attributed to pressure on the economy as a result of protracted strikes in the mining sector, the weakening of the rand and growing concerns about corruption in government and the nationalisation of private assets. That being said, the per capita gross domestic product (GDP) has increased as has household net wealth as a percentage of disposable income. One of the more concerning trends is the high unemployment rate (see the references to the 'Strict definition' rate and the 'Youth' unemployment rates in Figure 7 as alarming examples). The net result is that many South Africans continue to live in poverty.

What is most concerning is that South Africa continues to have one of the highest rates of inequality (GINI coefficient) in the world. ${ }^{15}$ As long is this persists crime and political instability will remain prevalent.

Obviously there is no such thing as an 'average South African' - the population of the nation is extremely diverse on a myriad of important levels, such as race, gender, class, age and location, to name but a few. However, the authors of the survey had to draw on a broad spectrum of averages based on statistical and economic data and tie that to shifts in the population as a whole over a 20-year period. What is clear, however, is that based on the statistical data, we would have to conclude, that in general South African's are enjoying comparatively better living conditions, well-being and quality of life in 2014 when compared to 1994.

What may be even more startling to some is that there was a marked improvement between 2004 and 2014 on issues of such as health care, economic well-being and housing, compared to the first 10 years of South Africa's democracy.

However, that being said, it must be stated strongly and clearly that we are far from where we need to be as a nation,

15.Please see the World Bank report on global inequality (cf. World Bank 2014). South Africa has a GINI coefficient of 63.1, which was the highest in the world at the time of the last data point for South Africa (2009). 


\begin{tabular}{|c|c|c|c|c|c|}
\hline \multirow[t]{2}{*}{ Indicator } & \multicolumn{3}{|c|}{ Year } & \multicolumn{2}{|c|}{ Change } \\
\hline & 1994 & 2004 & 2014 & 1994-2004 & 2004-2014 \\
\hline Life expectancy at birth (years) & 62.7 & 54.4 & 58.5 & & \\
\hline Crude death rate ${ }^{a}$ & 8.5 & 13.4 & 11.9 & & \\
\hline Child mortality rate ${ }^{b}$ & 62.0 & 73.0 & 45.7 & & \\
\hline Maternal mortality ratioc & $260(1995)$ & 147 & $91(2011)$ & & \\
\hline TB incidence ${ }^{d}$ & 309 & 898 & $1003(2012)$ & & \\
\hline Number of new TB cases ('000) & 130 & 430 & $530(2012)$ & & \\
\hline Number of HIV-infected people ('000) & 325 & 4590 & 5880 & & \\
\hline Number of new HIV infections ('000) & 237 & 497 & 321 & & \\
\hline Number of AIDS-related deaths ('000) & 8 & 252 & 203 & & \\
\hline Antiretroviral therapy coverage ${ }^{\mathrm{e}}$ & $1.0(2001)$ & 4.9 & $81.0(2013)$ & & \\
\hline Tobacco smoking ${ }^{f}$ & $32.0(1993)$ & $23.5(2003)$ & $16.2(2012)$ & & \\
\hline Food insecurityg & $52.3(1999)$ & $52.0(2005)$ & $26.0(2012)$ & & \\
\hline Enrolled nurses per 100000 population (public sector) & $59.7(2000)$ & $50.7(2005)$ & $69.5(2013)$ & & \\
\hline Medical practitioners per 100000 population (public sector) & $56.3(1996)$ & $21.6(2005)$ & $31.3(2013)$ & & \\
\hline Number of medical scheme beneficiaries (million) & 6.55 & 6.92 & $8.68(2012)$ & & \\
\hline $\begin{array}{l}\text { Number of deaths per } 1000 \text { population. } \\
\text { b Number of child deaths ( } 0-5 \text { years) per } 1000 \text { live births. } \\
\text { cNumber of women who die as a result of childbearing, during pregr } \\
\text { dNumber of TB cases (all types) per } 100000 \text { people. } \\
\text { eNumber of patients receiving ART, divided by the number needing } \\
\text { fo of population aged } 20 \text { years and above smoking tobacco. } \\
\text { PProportion of food insecure households. } \\
\text { Source: Actuarial Society of South Africa, } 2011 ; \text { Health Systems Trust }\end{array}$ & 42 days of deli & ermination of $p$ & $y$ in one year, pe & 00 live births. & \\
\hline
\end{tabular}

Source: Haldenwang, B., 2011, Projections of the South African population, 1985-2040 (With-AIDS and No-AIDS projections), Stellenbosch University, Bellville FIGURE 2: Quality of life profile. Health status, 1994, 2004 and 2014.

\begin{tabular}{|c|c|c|c|c|c|}
\hline \multirow[t]{2}{*}{ Indicator } & \multicolumn{3}{|c|}{ Year } & \multicolumn{2}{|c|}{ Change } \\
\hline & 1994 & 2004 & 2014 & 1994-2004 & 2004-2013 \\
\hline Adult illiteracy ${ }^{a}$ & $19.1(1996)$ & $17.9(2001)$ & $5.8(2012)$ & & \\
\hline Early childhood development ${ }^{\mathrm{b}}$ & n.a. & 405197 (2005) & $779370\{2013)$ & n.a. & \\
\hline Primary school enrolment ${ }^{c}$ & $7.89 \mathrm{~m}$ & $7.44 m$ & $7.06 \mathrm{~m}(2013)$ & & \\
\hline Secondary school enrolment ${ }^{d}$ & $3.52 \mathrm{~m}$ & $4.32 \mathrm{~m}$ & $4.59 \mathrm{~m}(2013)$ & & \\
\hline Numeracy performance in grade 3 (average score- $\%$ ) & n.a. & $30(2001)$ & $53(2013)$ & n.a. & \\
\hline Literacy performance in grade 3 (average score- $\%$ ) & n.a. & $30(2001)$ & $51(2013)$ & n.a. & \\
\hline Numeracy performance in grade 6 (average score- $\%$ ) & n.a. & 27 & $39(2013)$ & n.a. & \\
\hline Literacy performance in grade 6 (average score-\%) & n.a. & 38 & $59(2013)$ & 1. & \\
\hline Number of learners enrolled in grade 12 & 500000 & 505400 & $576500(2013)$ & & \\
\hline Number of grade 12 learners writing exam & n.a. & 468000 & $562100(2013)$ & & \\
\hline Grade 12 pass rate $(\%)$ & 58.0 & 70.7 & $78.2(2013)$ & & \\
\hline Grade 12 endorsement rate $(\%)$ & n.a. & 18.2 & $30.6(2013)$ & & \\
\hline$\%$ of schools without source of water on or near site & 33 (1996) & $11(2006)$ & $10(2011)$ & & \\
\hline$\%$ of schools without electricity on or near site & $57(1996)$ & $16(2006)$ & $14(2011)$ & & \\
\hline$\%$ of schools without on-site toilets & $12(1996)$ & $5(2006)$ & $4(2011)$ & & \\
\hline$\%$ of schools without a computer centre & $69(1996)$ & $68(2006)$ & $77(2011)$ & & \\
\hline Number enrolled at public higher education institutions & 525000 & 744000 & 938100 (2011) & & \\
\hline Number enrolled at public FET colleges & 302550 (1998) & 373453 & 400273 (2011) & & \\
\hline $\begin{array}{l}\text { apercentage of adult population (20+) without schooling. } \\
\text { bNumber of children enrolled in grade R. } \\
\text { cNumber of learners enrolled in grades } 1-7 . \\
\text { dNumber of learners enrolled in grades 8-12. } \\
\text { Source: Bot, 1995; Do BE, 2011a; } 2011 \text { b; 2013a; 2013b; 2013c; }\end{array}$ & $06 ; 2007 ; 2009 ;$ & 2013; StatsSA, 2 & 12a; 2013; Straus & aver & 200 \\
\hline
\end{tabular}

Source: Haldenwang, B., 2011, Projections of the South African population, 1985-2040 (With-AIDS and No-AIDS projections), Stellenbosch University, Bellville

FIGURE 3: Education status, 1994, 2004 and 2014. 


\begin{tabular}{|c|c|c|c|c|c|}
\hline \multirow[t]{2}{*}{ Indicator } & \multicolumn{3}{|c|}{ Year } & \multicolumn{2}{|c|}{ Change } \\
\hline & 1994/1995 & $2004 / 2005$ & $2012 / 2013$ & 1994-2005 & 2005-2013 \\
\hline Murder rate ${ }^{a}$ & 66.9 & 40.3 & 31.1 & & \\
\hline Attempted murder rate ${ }^{a}$ & 69.1 & 52.6 & 31.3 & & \\
\hline Sexual offence rate ${ }^{a}$ & n.a. & 148.4 & 127.0 & n.a. & \\
\hline Violent robbery rate ${ }^{a}$ & 218.5 & 272.2 & 202.6 & & \\
\hline Violent assault rate ${ }^{a}$ & 555.8 & 535.3 & 355.6 & & \\
\hline Common assault rate ${ }^{\mathrm{a}}$ & 516.0 & 575.0 & 330.8 & & \\
\hline Trio crime rate ${ }^{a}$ & n.a. & 54.0 & 84.8 & n.a. & \\
\hline Property-related crime rate ${ }^{a}$ & 1606.0 & 1282.0 & 1078.3 & & \\
\hline Commercial crime rate ${ }^{a}$ & 162.5 & 115.8 & 175.2 & & \\
\hline Drug-related crime rate ${ }^{a}$ & 118.4 & 180.3 & 395.6 & & \\
\hline Court cases prosecuted (cases finalised with verdict) & 267491 (1996) & 381020 & 323390 & & \\
\hline Conviction rate ${ }^{b}$ & $78.0(1996)$ & 85.1 & 89.9 & & \\
\hline Prison occupancy rate & 125 (1996) & 163 & 134 & & \\
\hline
\end{tabular}

Source: Haldenwang, B., 2011, Projections of the South African population, 1985-2040 (With-AIDS and No-AIDS projections), Stellenbosch University, Bellville FIGURE 4: Crime and viloence status, 1994/1995, 2004/2005 and 2012/2013.

\begin{tabular}{|c|c|c|c|c|c|}
\hline \multirow[t]{2}{*}{ Indicator } & \multicolumn{3}{|c|}{ Year } & \multicolumn{2}{|c|}{ Change } \\
\hline & 1996 & 2001 & 2011 & 1996-2001 & 2001-2011 \\
\hline Percentage of households living in informal dwellings & 16.2 & 16.4 & 13.6 & & \\
\hline Percentage of households living in formal dwellings & 65.1 & 68.5 & 77.6 & & \\
\hline Percentage of households living in two or less rooms & 32.6 & 33.4 & 28.7 & & \\
\hline Percentage of households without access to piped water & 19.7 & 15.0 & 8.8 & & \\
\hline Percentage of households with bucket toilets or less & 17.1 & 17.2 & 9.4 & & \\
\hline Percentage of households using electricity for lighting & 58.2 & 70.2 & 84.7 & & \\
\hline Percentage of households using electricity for cooking & 47.5 & 52.2 & 73.9 & & \\
\hline $\begin{array}{l}\text { Percentage of households with communal/own dump or } \\
\text { no refuse removal }\end{array}$ & 45.7 & 42.8 & 36.4 & & \\
\hline Percentage of households owning cell phone & n.a & 31.9 & 88.9 & n.a & \\
\hline
\end{tabular}

Source: Haldenwang, B., 2011, Projections of the South African population, 1985-2040 (With-AIDS and No-AIDS projections), Stellenbosch University, Bellville FIGURE 5: Housing and living, 2001 and 2011.

\begin{tabular}{|l|c|c|}
\hline Indicator & \multicolumn{2}{|c|}{ Year } \\
\cline { 2 - 3 } & $\mathbf{1 9 9 5}$ & $\mathbf{2 0 0 5}$ \\
\hline Human Development Index (HDI) value & 0.650 & $\mathbf{2 0 1 2}$ \\
HDI component: Life expectancy at birth & 59.9 & 0.604 \\
HDI component: Mean years of schooling & 8.2 & 51.1 \\
HDI component: Expected years of schooling & 13.1 & 8.2 \\
HDI component: GNI per capita (2005 PPP\$) & 7350 & 13.1 \\
Source: UNOP, 2013. & 8420 & 9.5 \\
\hline
\end{tabular}

Source: Haldenwang, B., 2011, Projections of the South African population, 1985-2040 (With-AIDS and No-AIDS projections), Stellenbosch University, Bellville FIGURE 6: Human development status, 1996, 2005 and 2012.

as the Institute for Futures Research report concludes (Haldenwang 2014:4). Regardless of these advances:

$[M]$ illions of South Africans (both young and old) continue to experience the negative impacts of two severe epidemics,
TB and HIV/AIDS, illiteracy, poor numeracy and literacy capabilities, inadequate education facilities, high crime rates, inadequate housing, water and sanitation facilities, unemployment and poverty. (Haldenwang 2014:4) 


\begin{tabular}{|c|c|c|c|c|c|}
\hline \multirow[t]{2}{*}{ Indicator } & \multicolumn{3}{|c|}{ Year } & \multicolumn{2}{|c|}{ Change } \\
\hline & 1994 & 2004 & 2013 & 1994-2004 & 2004-2013 \\
\hline \multirow{2}{*}{ Economic growth (\% per annum) } & 3.2 & 4.6 & 1.9 & & \\
\hline & 8.9 & 1.4 & 5.7 & & \\
\hline Inflation & R28 536 & R31 704 & R37 700 & & \\
\hline Real gross domestic product (GOP) per capita & R29146 & $R 29883$ & R40 531 & & \\
\hline Real gross domestic spending (GDE) per capita & & & & & \\
\hline Household net wealth as $\%$ of disposable income & 296.6 & 270.2 & 328 & & \\
\hline Real final consumption expenditure (FCE) per capita & R17 628 & R19 832 & R25 060 & & \\
\hline labour force participation rate ${ }^{\mathrm{a}}$ & 54.7 & 52.8 & 52.1 & & \\
\hline labour absorption rate ${ }^{b}$ & 43.8 & 39.8 & 39.0 & & \\
\hline Unemployment rate (strict definition)(\%) & 20.0 & 24.7 & 25.3 & & \\
\hline Youth labour force participation rate ${ }^{c}$ & 33.1 & 28.6 & 26.3 & & \\
\hline Youth absorption rate ${ }^{d}$ & 20.1 & 13.9 & 12.3 & & \\
\hline Youth unemployment rate $(\%)$ & 39.4 & 51.3 & 53.0 & & \\
\hline Youth-to-adult ratio of unemployment rate & 2.6 & 2.6 & 2.5 & & \\
\hline Number of poor people (upper-bound poverty line $\mathrm{e}^{\mathrm{a}}$ & $22.6 \mathrm{~m}(1993)$ & $22.6 \mathrm{~m}(2006)$ & $23.0(2011)$ & & \\
\hline Percentafl of population that is poor (upper-bound poverty line $\mathrm{e}^{\mathrm{e}}$ & $57.0(1993)$ & $57.2(2006)$ & 45.5 (2011) & & \\
\hline Number of extremely poor people (food poverty line) ${ }^{f}$ & $13.1 \mathrm{~m}(1993)$ & $12.6 \mathrm{~m}(2006)$ & $10.2 \mathrm{~m}(2011)$ & & \\
\hline Number of extremely poor people (food poverty line) ${ }^{f}$ & $33.0(1993)$ & $26.6(2006)$ & $20.2(2011)$ & & \\
\hline $\begin{array}{l}\text { The proportion of the working age population ( } 15-64 \text { years) that is econ } \\
\text { The proportion of the working age population ( } 15-64 \text { years) that is empl } \\
\text { The proportion of the youth population (15-24 years) that is economical } \\
\text { 'The proportion of the youth population ( } 15-24 \text { years) that is employed. } \\
\text { "The upper-bound poverty line is defined as R193.61 per capita in 1993, } \\
2011 \text { (inflation-adjusted). } \\
\text { The food poverty line is defined as R88.71 per capita in 1993, R210 per c } \\
\text { Source: LLO, 2014; SA Reserve Bank, various years; StatsSA, 2014a; 2014t }\end{array}$ & $\begin{array}{l}\text { capita in } 2004 \text { ar } \\
2004 \text { and R321 pe } \\
\text { esidency, } 2014 .\end{array}$ & $\begin{array}{l}\text { per capita in } \\
\text { a in } 2011 \text { (inflatior }\end{array}$ & & & \\
\hline
\end{tabular}

Source: Haldenwang, B., 2011, Projections of the South African population, 1985-2040 (With-AIDS and No-AIDS projections), Stellenbosch University, Bellville

FIGURE 7: Economy, income and employment status, 1994, 2004 and 2013.

In short, while South Africans may be comparatively better off, yet we are still nowhere near where we should be as a nation. When one is rising from a low base any improvement is positive, but we cannot sit back and say that we have made sufficient progress. There is work to do and as was argued in the previous sections the church has a critical present role to play in working towards a more desirable future for South Africa.

However, when we say the church has a role to play, what are we referring to? What is the church we are speaking of?

\section{The church of Hope}

The 'Message to the People of South Africa' (SACC 1968), referred to earlier in this paper, had this to say about the public role, witness and mission of the church in society:

The task of the Church is to enable people to see the power of God at work, changing hostility into love of the brethren, and to express God's reconciliation here and now. For we are not required to wait for a distant 'heaven' where all problems will have been solved. What Christ had done, he has done already. We can accept his work or reject it; we can hide from it or seek to live by it. But we cannot postpone it, for it is already achieved; and we cannot destroy it, for it is the work of the eternal God. (SACC 1968; quoted in Naudé 1995:169)

Russel Botman, said in his inaugural address as Rector of Stellenbosch University: 'Africa will yet rise to challenge of the hope that God has for it and for its people. The church and theological education is crucial to this mission' (Smit 2007:58). Indeed, the church does have a role to play in the future of South Africa, if not simply by its sheer numbers in our population. Nieman comments that, 'the 23 main religious groupings, with a membership of $37,157,820$ in 2001 ( $84 \%$ of the population) represent a potentially powerful voice and resource' (Nieman 2010:37).

Both Botman and 'A message to the People of South Africa' (SACC 1968) operate from the perspective of current action and future hope - what Vorster and Küng call a 'presentfuturist eschatology' (For the original reference please see Küng 1992:59; Vorster 2011:7-8). However, the question is what do we mean by the expression 'church'? Dirkie Smit (1996) suggests that there are three general forms of being 'the church' (Smit 2007:61-68). I shall briefly present these below.

\section{The local congregation}

For many Christians the local congregation is most likely to be their primary understanding of the church. Namely, that the church is a localised community of Christians, organised around regular common worship. Philander points out that this is the place, and social group, that people often think of when they answer the question of where they go to church, or what church they are members of or belong to (Philander 2011:177). What role can this 'form' of church play in taking 
South Africa forward in hope in the next 20 years? As Smit rightly points out, this requires careful reflection. Firstly, it is important to recognise that the largest grouping of South Africa's Christians belong to African Initiated churches. The last reliable census data showed that $48 \%$ of South Africa's Christian population fit into such church groupings (Statistics South Africa 2001), ${ }^{16}$ with a further 31\% belonging to other groupings that include the mainline denominations. Some scholars argue that these local communities provide a great deal of social cohesion, faith identity that fosters hope, and at times even concrete expressions of hope (such as feeding schemes, education, skills development, and social care) (Nieman 2010:37-44). There are numerous examples of individuals whose lives have been positively changed and transformed, perhaps even of communities that have experienced such transformation, as a result of the positive contribution of a local worshipping community.

Quite apart from the immeasurable spiritual value and the work of moral formation added through local worshipping communities, there is another way in which such communities act in the present to bring hope for the future (Philander 2011:176-179). This level of involvement in the local community is often described as first and second generation involvement, to use the terminology of David Korten (1990:117-118). First generation engagement can refer to relief and charity work (soup kitchens, child care, education, basic medical care etc.), whereas second generation engagement can refer to the work of empowering a community, often through projects (such as skills development projects examples could include sewing classes, trades etc.).

However, we also cannot deny that while this form of church has potential for great good, it also has the potential for great harm. ${ }^{17}$ Many of the leaders of these communities are self-appointed pastors who lack formal theological training and do not adhere to structures of governance or oversight that would be common in mainline denominations. The rampant spread of churches that preach a prosperity doctrine is alarming, as is the rise of fundamentalism and religious intolerance. While such aspects are often quite noticeable in society, there are also other ways in which this form of community could contribute negatively towards society. John de Gruchy notes that at times in our own history, church worship, teaching and liturgy have been the cause of preventing the gospel from taking hold in society (De Gruchy 1986; Smit 2007:63). Smit notes that this may not be the kind of contribution that theologians, or religious leaders, would like to see (Smit 2007:63).

The challenge is thus to engage with this popular and ever growing sector of Christian community with a theology of hope in order to work for the good of South Africans in the next 20 years, and also to avert any possibly harmful

\footnotetext{
16.For a thorough theological discussion please see Hendriks \& Erasmus (2005).
}

17.The Christian religion is also a dangerous power, and has been such and still is, in South Africa (Smit 2007:63). social, religious and theological impact on society from such groupings.

\section{The institutional, denominational and ecumenical church}

For many people the 'church' refers primarily to the organisational or institutional structures. When some people hear the word 'church' in this context they may think of the confessional community that they are a part of (e.g., Catholic, Orthodox or Methodist). Philander notes that often this expression of church is what people would point to in answer to the question 'what does the church say about unemployment in South Africa?' (Philander 2011:177). It could also refer to larger collective groupings such as Evangelical Christians, or even more formal groupings such as ecumenical bodies (like the World Council of Churches, or the World Communion of Reformed Churches). Smit notes that we must take care not to confuse numerical prominence of a grouping with the social and theological contribution of that church (Smit 2007:65). Simply knowing how many Methodists, or Charismatics there are in South Africa does not tell us much about their contribution to society. Take the Methodist Church of Southern Africa as an example, even though it is one denomination, there are at least two distinct churches within this grouping. The largest is a predominantly black membership whose style of worship is liturgical and theological perspective is evangelical, with uniformed organisations that are lead mostly by lay preachers and lay leaders. The second is a predominantly white and coloured grouping that is both less liturgical and less evangelical. The hopes and aspirations of these two groupings, in this single denomination will vary significantly..$^{18}$ It would be safe to accept that the same goes for Charismatic, Reformed and other denominational or ecumenical groupings in South Africa that have racially and economically diverse membership.

In previous decades this form of church would be understood to engage society with a third generation development strategy, namely to engage the policies of institutions in society (such as the policies and laws of government, and the decisions and policies of regulatory bodies in society etc.) (Korten 1990:119; Nieman 2010:38).

A recent academic article on the changes in expectations of members, and the ministry models of South African churches, noted the demise of the ecumenical movement in South Africa (Forster 2014). The consequences are that the church has been left somewhat weakened and voiceless in the new dispensation. Unlike the period leading up to 1994 there is thankfully no longer a state church that can speak on behalf of the people, and sadly no longer a struggle church linked to a strong functional ecumenical body, like the South African Council of Churches, that represents the collective will and intentions of the churches in South Africa. Smit (2007:66) notes that the ecumenical movement that was 'strong during the apartheid years when many

18.Please see the following section for a discussion of some of the distinctive elements of the different groupings in South African Methodism (Forster \& Bentley 2008:87-90). 
churches were committed to their common struggle against apartheid, has lost most of its appeal and influence'. The aforementioned article by Forster (2014) draws on research conducted among Christians across South Africa that shows that with the demise of traditional ecumenical structures new groupings have emerged in an attempt to fulfil this vital social and public role of the church. Examples of such movements are the Religious Leaders Forum, South African Christian Leaders Initiative (SACLI), Unashamedly Ethical, Transformation Africa, and most recently the controversial ForSA movement. Of course many denominations continue to be active in their prophetic work and witness in the public sphere. One could cite many wonderful examples of projects that denominations and groupings are involved in that are having a significant impact on society. The SACLI, for example, were engaged in such important social action and witness when the office of the Public Protector, and other section 9 institutions that protect the constitution of South Africa, came under threat from the Presidency and the governing party (SAPA 2014). However, in terms of a theology of hope there is significant scope for greater partnership, particularly as it relates to engaging policy issues in South African society.

\section{The church as believers, salt and light in the world}

The third way in which people think of the church, is as individual believers who are salt and light in the world, each involved in living out their faith on a daily basis in their own particular way (Smit 2007:68). This is a very important manner in which the church can participate in being a bearer of hope in society. A group of Christians recently conducted a broad-based empirical survey across South Africa on the role of Christians as 'salt and light' in the world of work. In their introduction they explain why they felt motivated to conduct this research:

God's ultimate plan is to redeem all parts of creation back to Him [sic]. This includes hearts, minds, culture, nature, environment, government, law, media, craft, relationships, education etc. God has not called us out of the workplace, but he has specifically planted us in the workplace for a definite reason. It's [sic] important that the body of Christ understand [sic] that we are called to fill every position that exists; teachers, principals, political positions, industries ... every business that exist [sic] ... with a mission to manifest the Kingdom of God. (Call42 2013a)

While one may not agree with every theological tenet in the above statement, it is encouraging that lay Christians are seeking to be intentional about their ministry in working for God's will in the world. The research shows that some Christians have a clear understanding that they have a task and a role to play as beaerers of God's hope in society. However, the reality is that such a perspective is a minority view among both South African Christians and churches. An analysis of the Call42 data showed the following:

- Christians in South Africa are struggling to find significant meaning and purpose in their work.

- There is a hunger for a deeper focus on God and the principles of God's kingdom in every aspect of life (both those parts that are formed around the gathered church, and those parts that are formed around the scattered church).

- It appears that churches struggle to adequately envision, equip and support Christians in the world of work. There is not sufficient training and support for business leaders and employees.

- A professional career matters to God and is useful for the purpose of advancing God's kingdom in society (Call42 2013b:1-2; Forster 2014:5).

In an ideal situation the contribution of the church would be characterised as a fourth generation contribution, to use Korten's terminology once again (Korten 1990:113-132). Fourth generation engagement is:

[A]kin to a social movement that makes extensive use of networks and people's independent mobilising actions to work for justice and people's self-actualisation in society. It is guided by an alternative vision in society that mobilises people to voluntary action. (Swart, Rocher \& Erasmus 2010:8)

Events such as the eviction of informal dwellers from land owned by the South African National Roads Agency in Lwandle and Nomzamo on the 4th of June 2014 evoked such a fourth generation response among local Christian communities. When the public saw Murray Williams' pictures of people struggling to save their meagre belongings, being exposed to the rain and cold, they were incensed and gathered in support of the community (Williams 2014a, 2014b). The public outcry put a halt to the injustice, and even garnered apologies from government officials (Williams 2014b). It was the presence of Christians on the ground (particularly the work of Methodist Bishop, Michel Hansrod), local ministers and members of churches, that helped to bring the injustice to light and helped to bring about a tentative solution.

Gerald West (in press) challenged the church to recover the importance of people's theology in a paper he delivered at Stellenbosch University entitled, 'People's theology, prophetic theology, and public theology in post-liberation South Africa'. ${ }^{19}$ In his paper he writes how biblical scholars and theologians have been engaging with social movements like Abahlali baseMjondolo [shack dwellers]. His challenge reminds us of Albert Nolan's (1988) description of the South African church, the majority church, that is seldom represented in the secular or Christian media:

The part of the Church that I am referring to is the oppressed part, the poor and the oppressed Christians of South Africa ... This cuts across all our Church denominations and includes leaders from various traditions. In fact, this part of the Church must now be, far and away, the majority of Christians in South Africa. (p. 211)

Indeed, this is the church in South Africa. The church in South Africa remains largely poor, it is largely female, and it is largely between the ages of 15-65 (as the most recent statistics on the South African population [Haldenwang 2014:1] and

19.Prof West's paper will appear as a chapter in a book edited by Claassens \& Birch (in press). 
Church membership [Nieman 2010:37] show). One could ask whether the leadership of church denominations, and academics in theological institutions, are engaging this church as we think about the future of South Africa, and the role of the church in that future?

\section{Conclusion}

This article has made two overarching points. Firstly, that Christians and the church have a contribution to make as bearers and vessels of hope in South Africa. The research showed that at times we have not adequately understood either the complexity of a theology of hope, or the experience of suffering and discontent at the slow and inadequate pace of change in South Africa. For this reason the article adopted a public theological approach that allowed for a textured and nuanced understanding of hope to emerge in dialogue with findings of the OECD 'Better Living Index' data. In order to understand how the church is, and can be, a bearer of hope, different forms of the church were discussed. This nuanced view of the three primary expressions of church in South Africa offers a theological framework out of which different expressions of hope can emerge in South Africa. The discourse of a theology of development showed that there are various levels of bearing and witnessing to hope, from policy engagement, to addressing primary felt needs in society. A clear conclusion that emerged from this public theological discourse was that all of these forms of church must engage with the reality of the current social and demographic context in order to effectively act as bearers of hope. Secondly, the article showed that while there had been some positive developments in the 20 years since 1994 the church cannot say that South African society is just, equitable and a reflection of the eschatological hope that God has for society. Within this context of injustice and suffering a 'present-futurist eschatology' must be adopted since it helps the church, and Christians, to act concretely and courageously in the present for a desired future reality.

Such an approach to eschatological hope is summed up in the following quote: 'Hope is hearing the melody of the future. Faith is to dance it' (Alves 1972:195; Bedford-Strohm 2011:191)

\section{Acknowledgements Competing interests}

The author declares that he has no financial or personal relationships which may have inappropriately influenced him in writing this article.

\section{References}

Actuarial Society of South Africa, 2011, 'ASSA2008 AIDS and demographic model', viewed 20 June 2014, from http://www.actuarialsociety.org.za

Alves, R.A., 1972, Tomorrow's child; imagination, creativity, and the rebirth of culture, Harper \& Row, New York.

Bedford-Strohm, H., 2011, Prophetic witness: An appropriate mode of public discourse in democratic societies?, Lit Verlag, Münster.

Bentley, W., 2004, 'The kingdom of God in Moltmann's eschatology: A South African perspective', viewed 20 June 2014, from http://www.repository.up.ac.za/ handle/2263/28667
Bentley, W., 2008, 'Karl Barth's definition of church in politics and culture: Growth points for the church in South Africa', HTS Theological Studies/Teologiese Studies 63(4), 1643-1661.

Bentley, W., 2013, 'Defining Christianity's "prophetic witness" in the post-apartheid South African democracy', Studia Historiae Ecclesiasticae 31(1), 1-7.

Call42, 2013a, 'Introduction to Call42', viewed 13 September 2013, from http://www. call42.co.za/about/

Call42, 2013b, 'Survey: Top challenges', pp. 1-7, viewed 13 September 2013, from http://www.call42.co.za/wp-content/uploads/2012/07/Call42-Top-ChallengesFinal-April-2013.pdf

De Gruchy, J.W., 1986, Cry justice!: Prayers, meditations, and readings from South Africa, Orbis Books, London.

De Gruchy, J.W., 2013, Led into mystery: Faith seeking answers in life and death, SCM Press, Canterbury.

Dubner, S.J. \& Levitt, S.D., 2014, Think like a freak, Penguin Books Limited, London.

'EFF makes ANC see red', 2014, The Star, viewed 20 June 2014, from http://www.iol. co.za/the-star/eff-makes-anc-see-red-1.1691738\#.U4M3ehaOflo

Ellis, A.K., 1970, Teaching and learning elementary social studies, Allyn and Bacon, Boston.

Erasmus, J., 2012, 'Religious demographics in post-apartheid South Africa', in I. Swart, A. Gouws, P. Petersen, J. Erasmus \& F. Bosman (eds.), Welfare, religion and gender A. Gouws, P. Petersen, J. Erasmus \& F. Bosman (eds.), Welfare, religion and gender
in post-apartheid South Africa: Constructing a south-north dialogue, pp. 43-64, in post-apartheid South Africa: Const
African Sun MeDIA, Stellenbosch.

Ford, D., 2013, Theology: A very short introduction, Oxford University Press, Oxford. http://dx.doi.org/10.1093/actrade/9780199679973.001.0001

Forster, D.A., 2008, 'More red than green: A response to global warming and the environment from within the Methodist Church of Southern Africa', Epworth Review 35(2), 38-52.

Forster, D.A., 2014, 'Called to work: A descriptive analysis of Call42's research on faith and work in South Africa', Koers: Bulletin for Christian Scholarship 79(2), 1-9. http://dx.doi.org/10.4102/koers.v79i2.2143

Forster, D.A. \& Bentley, W., 2008, Methodism in Southern Africa: A celebration of Wesleyan Mission, AcadSA Publishers, Kempton Park.

Gibson, N.C., 2012, 'What happened to the "Promised land"? A Fanonian perspective on post-apartheid South Africa', Antipode 44(1), 51-73. http://dx.doi. org/10.1111/j.1467-8330.2010.00837.x

Haldenwang, B., 2011, Projections of the South African population, 1985-2040 (With AIDS and No-AIDS projections), Stellenbosch University, Bellville.

Haldenwang, B., 2014, '20 years of democracy: Is life better or worse for the "average" South African?', Institute for Futures Research 19(2), 1-6.

Harvie, T., 2009, Jürgen Moltmann's ethics of hope: Eschatological possibilities for moral action, Ashgate Publishing, London.

Hauerwas, S., 2013, Approaching the end: eschatological reflections on church, politics, and life, Wm. B. Eerdmans Publishing, Grand Rapids.

Hayes, S., 2008, 'The Message to the people of South Africa - 40 years, Khanya e isoe ho Molimo holimo', viewed 28 May 2014, from http://khanya.wordpress. com/2008/05/06/the-message-to-the-people-of-south-africa-40-years

Health Systems Trust, 2014, 'Health statistics', viewed 20 June 2014, from http://www. hst.org.za/health-indicators-advanced-search

Hendriks, J. \& Erasmus, J., 2005, 'Religion in South Africa: 2001 population census data', Journal of Theology for Southern Africa 121, 88-111.

Hermans, C., 2012, 'Towards a "U-turn" by the churches: How (Not) to possibilise the future', Religion \& Theology 19, 237-264. http://dx.doi.org/10.1163/1574301212341241

Human Sciences Research Council, 2013, The South African National Health and Nutrition Examination Survey, HSRC Press, Cape Town. (SANHANES, 1)

Kairos Theologians, 1985, Challenge to the Church: A theological comment on the political crisis in South Africa, The Kairos Theologians, Johannesburg.

Koopman, N., 2011, 'Modes of prophecy in a democracy', in H. Bedford-Strohm \& E. de Villiers (eds.), Prophetic witness: an appropriate mode of public discourse in democratic societies?, pp. 181-192, LIT Verlag, Münster. (Theology in the Public in democratic societies?, $\mathrm{pp}$. 181-192,
Square/Theologie in der Öffentlichkeit).

Koopman, N., 2014, 'Hunger and thirst for a society of compassionate justice. The role of activistic churches?', paper delivered at the Stellenbosch University Winter role of activistic churches?, paper delivered at the Stellenbosch University Winter pp. 1-4.

Korten, D.C., 1990, Getting to the 21st century: Voluntary action and the globa agenda, Kumarian Press, West Hartford.

Küng, H., 1992, Die Kirche, Piper Verlag, München.

Maluleke, T.S., 2011, 'Reflections and resources the elusive public of Public Theology: A response to William Storrar', International Journal of Public Theology 5(1) 79-89. http://dx.doi.org/10.1163/156973211X543751

Mashele, P. \& Qobo, M., 2014, The fall of the ANC: What next?, Picador Africa, Johannesburg.

Meeks, M.D., 1974, Origins of the theology of hope. Fortress Press, Philadelphia.

Moltmann, J., 1993, Theology of hope, Fortress Press, Philadelphia.

Mouton, A.E.J., 2001, 'Remembering forward and hoping backward?', Scriptura 76 77-86.

Naudé, B., 1995, My land van hoop: Die lewe van Beyers Naudé, Human \& Rousseau, Cape Town. 
Nieman, A., 2010, 'Churches and social development in South Africa', in I.W. Swart, H. Rocher, J. Erasmus \& S. Green (eds.), Religion and social development in postH. Rocher, apartheid South Africa, pp. 37-44, SUN Press, Stellenbosch.

Nolan, A., 1988, God in South Africa: The challenge of the Gospel, Eerdmans, Grand Rapids.

Organization for Economic Co-operation and Development (OECD), 2013a, 'How's life? 2013', pp. 17-31, viewed 03 June 2014, from http://www.keepeek.com/ Digital-Asset-Management/oecd/economics/how-s-life-2013_9789264201392en\#page 1

Organization for Economic Co-operation and Development (OECD), 2013b, OECD Economic Surveys: South Africa 2013, OECD Publishing, Paris.

Philander, N.C., 2011, 'Die rol van die kerk as een van die instellings in die samelewing wat mense moreel vorm', Dutch Reformed Theological Journal/Nederduitse Gereformeerde Teologiese Tydskrif 52(1/2), 174-185.

Plaatjies-Van Huffel, M-A. \& Vosloo, R. (eds.), 2013, Reformed Churches in South Africa and the Struggle for Justice: Remembering 1960-1990, African SUN MeDIA Stellenbosch.

Polak, F.L., 1968, De toekomst is verleden tijd: Cultuur-futuristische verkenningen, De Haan, Utrecht.

Polak, F.L., 1971, Prognostics: a science in the making surveys and creates the future, Elsevier, Amsterdam.

Rahner, K-J., 1992, Karl Rahner: Theologian of the graced search for meaning, Fortress Press, Minneapolis.

SAPA, 2013, 'Church's call angers SADTU', Independent Online News, viewed 20 June 2014, from http://www.iol.co.za/news/south-africa/gauteng/church-s-callangers-sadtu-1.1587664\#.U5Vtsha0flo

SAPA, 2014, 'Archbishop criticises Madonsela attacks' Cape Argus, viewed 20 June 2014, from http://www.iol.co.za/news/politics/archbishop-criticises-madonselaattacks-1.1663325\#.U_swlBaOflo

Scharmer, C.O., 2009, Theory U: Learning from the future as it emerges, BerrettKoehler Publishers, San Francisco.

Smit, D.J., 1996, 'Oor die kerk as 'n unieke samelewingsverband', Tydskrif vir Geesteswetenskappe 2(36), 119-129.

Smit, D.J., 2007, Essays in Public Theology: Collected Essays, 1, African SUN MeDIA Stellenbosch.

Smit, D.J.,. 2013, 'The paradigm of Public Theology - origins and development', in H. Bedford-Strohm, F. Höhne \& T. Reitmeier (eds.), Contextuality and intercontextuality in Public Theology, pp. 11-23, LIT Verlag, Münster.
South Africa, The Presidency, 2014, Twenty year review: South Africa, 1994-2014, The Presidency of South Africa, Pretoria.

South African Council of Churches (SACC), 1968, 'A message to the people of South Africa', South African Council of Churches, Johannesburg viewed 20 June, 2014, from http://www.sacc.org.za/ARCHIVED\%20SACCNEWS/about/ celebrate16.html

Statistics South Africa, 2001, 'Census 2001', viewed 10 June 2014, from http://www. statssa.gov.za/census01/html/default.asp

Swart, I. (Naas) W., Rocher, H. \& Erasmus, J., 2010, Religion and social development in post apartheid South Africa: Perspectives for Critical Engagement, SUN Press, Stellenbosch.

Tshaka, R.S., 2014, 'A perspective on notions of spirituality, democracy, social cohesion and public theology', Verbum Ecclesia Verbum et Ecclesia 35(3), 1-7. http://dx.doi. org/10.4102/ve.v35i3.1336

United Nations Development Programme (UNDP), 2012, 'Human Development Report 2013: The rise of the South: Human progress in a diverse world: South Africa', viewed 20 June 2014, from http://hdr.undp.org/sites/default/files/ Country-Profiles/ZAF.pdf

Van Aarde, A., 2008, "What is "theology" in "public theology" and what is "public" about "public theology?", HTS Teologiese Studies/Theological Studies 64(3) http://dx.doi.org/10.4102/hts.v64i3.81

Van de Laar, J., 2010, The hour that changes everything: How worship forms us into the people god wants us to be, Sacredise Publishing, Cape Town.

Vorster, J.M., 2011, 'An ethics of hope for moral renewal in South Africa', Journal of Theology for Southern Africa 140, 4-19.

West, G. (in press), 'People's theology, prophetic theology, and public theology in post-liberation South Africa', in J. Claassens \& B. Birch (eds), Restorative readings: Old Testament, ethics, human dignity, Wipf and Stock Publishers, Eugene.

Williams, M.,2014a, 'Lwandleeviction battle:PICS', CapeArgus, viewed20June2014, from http://www.iol.co.za/news/crime-courts/Iwandle-eviction-battle-pics-1.1697669? showComments=true\#.U_szlBaOflo

Williams, M., 2014b, 'We'll never see evictions like that again', Cape Argus, viewed 20 June 2014, from http://www.iol.co.za/capeargus/we-ll-never-see-evictions-likethat-again-1.1699973\#.U5Xc6xa0flo

World Bank, 2014, 'GINI index', viewed 20 June 2014, from http://data.worldbank. org/indicator/SI.POV.GINI

World Health Organization (WHO), 2014, 'Global TB database', viewed 20 June 2014, from http://www.who.int/tb/country/global_tb_database/ 